\title{
Surveys as Means of Understanding User-behaviour with Respect to Energy Usage in Households, Prior to Decision-making to Promote Sustainability
}

\section{Badania ankietowe jako sposób zrozumienia zachowania użytkowników w odniesieniu do zużycia energii w gospodarstwach domowych, przed podjęciem decyzji w celu promowania zrównoważonego rozwoju}

\author{
G Venkatesh ${ }^{\star}$, Are Kjeang ${ }^{\star \star}$ \\ Department of Engineering and Chemical Sciences of Karlstad University, \\ Karlstad, Sweden \\ E-mails:*venkatesh.govindarajan@kau.se(corresponding author),**are.kjeang@kau.se
}

\begin{abstract}
Households account for varying shares of total energy usage in countries, depending on the degree of industrialization. In order to design effective policy instruments and set appropriate levels for subsidies, knowing the attitudes and perceptions of users with respect to energy usage and energy saving is always the first step. In this article, the authors have first presented a comparative analysis and critique of selected recently-published surveys (2018) related to energy use in households, from around the world, before applying the sustainability-thinking paradigm to their own regional survey of close to 300 single-family households (detached houses and row houses) carried out in Karlstad (south-central Sweden), to obtain insights into user attitudes and preferences - categorised into the three dimensions of sustainability - when it comes to energy usage or decision-making with regard to retrofits or new energy-using / energy-saving installations in households. Each of the dimensions is characterised by three criteria which respondents have rated on a Likert's scale of 0 to 4 (not important to very important). The findings from this survey will open up a new way of thinking about the heterogeniety of energy users (which needs to be respected), for decision-makers and energy-advisers, who could subsquently strengthen their interaction and communication with them.
\end{abstract}

Key words: energy saving, energy use, households, surveys, Sweden, sustainability

\section{Streszczenie}

Gospodarstwa domowe w poszczególnych krajach mają różny udział w całkowitym zużyciu energii, w zależności od stopnia uprzemysłowienia. W celu zaprojektowania skutecznych instrumentów polityki i ustalenia odpowiednich poziomów dotacji, znajomość postaw i opinii użytkowników w odniesieniu do zużycia energii i oszczędzania energii jest zawsze pierwszym krokiem. W tym artykule autorzy najpierw przedstawili analizę porównawczą $\mathrm{i}$ krytykę wybranych niedawno opublikowanych badań (2018) związanych z zużyciem energii w gospodarstwach domowych z całego świata, a następnie zastosowali paradygmat myślenia o zrównoważonym rozwoju do własnych badań regionalnych odnoszących się do 300 domów jednorodzinnych (domy jednorodzinne i szeregowe) przeprowadzonych w Karlstad (południowo-środkowa Szwecja) w celu uzyskania wglądu w postawy i preferencje użytkowników - podzielone na trzy wymiary zrównoważonego rozwoju - w kontekście zużycia energii lub podejmowania decyzji w odniesieniu do modernizacji lub montowania nowych instalacji wykorzystujących energię / energooszczędnych w gospodarstwach domowych. Każdy z wymiarów charakteryzuje się trzema kryteriami, które respondenci ocenili w skali Likerta od 0 do 4 (nieważne do bardzo ważnych). Wyniki tego badania otworzą 
nowy sposób myślenia o heterogeniczności użytkowników energii (co należy szanować) dla decydentów i doradców energetycznych, którzy mogliby następnie wzmocnić interakcje i komunikację z nimi.

Slowa kluczowe: oszczędzanie energii, zużycie energii, gospodarstwa domowe, badania ankietowe, Szwecja, zrównoważoność

\section{Introduction}

The ongoing concerns about global warming and climate change and the diverse adverse effects of the same have generated interest among governments, industries and researchers in collaborating to understand the possibilities of optimising energy use. Technological developments apart, long-term holistic thinking supported by different policy instruments, such as regulations, energy advising and subsidies, is needed.

Households account for varying shares of total energy usage in countries, depending on the degree of industrialization. In order to design effective policy instruments and set appropriate levels for subsidies, knowing the attitudes and perceptions of users with respect to energy usage and energy saving is always the first step (Stern, 1992). Measuring energy use in households, according to Darby (2006), encouraging users to keep a log of the same (Ellegård et al., 2011), providing weekly feedback via e-mail (Burchell et al., 2016), and home-visits by energy advisers to provide lucid and easily-understandable advice are good ways to sustain interest in issues related to energy efficiency.

Energy efficiency is often a poorly-understood concept in households. There is a better appreciation of aspects like comfort levels, proper lighting, warm water in the desired quantities and reliable electricity supply to power the electronics and white goods in the households. Energy advisers need to be empathetic and sensitive to this fact, and also realise that the decision-making adults in households may not be in a position to make rational decisions consistently (Tjörring et al., 2015; Aune 2007). Habits are formed and entrenched in a human being's childhood-years; and thereafter, with time, they become increasingly difficult to alter. This is true even within the realm of energy use in households. However, there are always opportunities when new habits can be formed as replacements of the undesirable ones. There are the so-called new starts in a person's life marked by the purchase of a new home, the birth of a child in the family or a relocation to a new town/city/country (Klöckner, 2015). Research and surveys have indicated that norms which are established in the society of which a household is a part of, also play a key role in influencing energy-use behaviour (Schultz et al., 2007; Alcott, 2011).

Socio-economically, there was a relatively strong commitment in the 1980s that Sweden should get rid of its dependency on oil. Oil was expensive as well as deterimental to the environment. Later, in the 1980's and 1990's the environmental aspect was added. In Kjeang et al. (2017), the authors have noted that there is an absence of publications discussing energy-advising from a triple-bottom-line / sustainability perspective. As indicated in Kjeang et al. (2017), the imperativeness of an interdisciplinary approach has also been emphasized by Steg (2008). As depicted in Figure 1, a tendency on the part of energy users to emulate good behaviour they see around them is a plus. Here, one must mention the EU's Empowering project, in which consumers are provided information about not only their own electricity consumption but also of others who have similar lifestyles and reside in similar dwellings (Nakano R. et al., 2018). A tendency to continue undesirable practices, on account of inertia to change of any kind (lock-ins), a fear of disapproval by neighbours, an over-valuation of comfort, aesthetics and convenience at the expense of environment-friendliness or economic feasibility, is a negative social aspect. Economically, returns on investment may be attractive or otherwise, depending on the financial status of the energy-user. Highly-affluent energy users may not value relatively-small long-term savings, as much as users who find it difficult to make ends meet may do. Furthermore, oftentimes, in the absence of a lifecycle thinking approach, the high initial cost which reduces operational and maintenance expenses, and thereby the life-cycle cost, could be a major deterrent. However, for an environmentally-friendly wealthy individual, a higher initial investment to contribute to a reduction in environmental impacts, will be an attractive option, irrespective of what the life-cycle costs are. Environmentally, every society would have its transcendental altruistic carers of the environment as well as those who do not or cannot understand the fact that sustained socio-economic well-being is very much dependent on sustained good health of the environment. However, environmental sustainability is multi-pronged and entails both optimised use of resources as well as reduction of emissions to the different spheres of the environment; and trade-offs are often called for. It must also be mentioned at this juncture that the households sector may even dominate the total energy consumption of some regions, provinces within countries, or even countries which are not very highly industrialised; and in such cases, modelling, understanding and influencing energy use in this sector is of much greater importance. It goes without saying that sustainable consumption and sustainable production have to go hand in hand if global sustainable development is to become possible. 


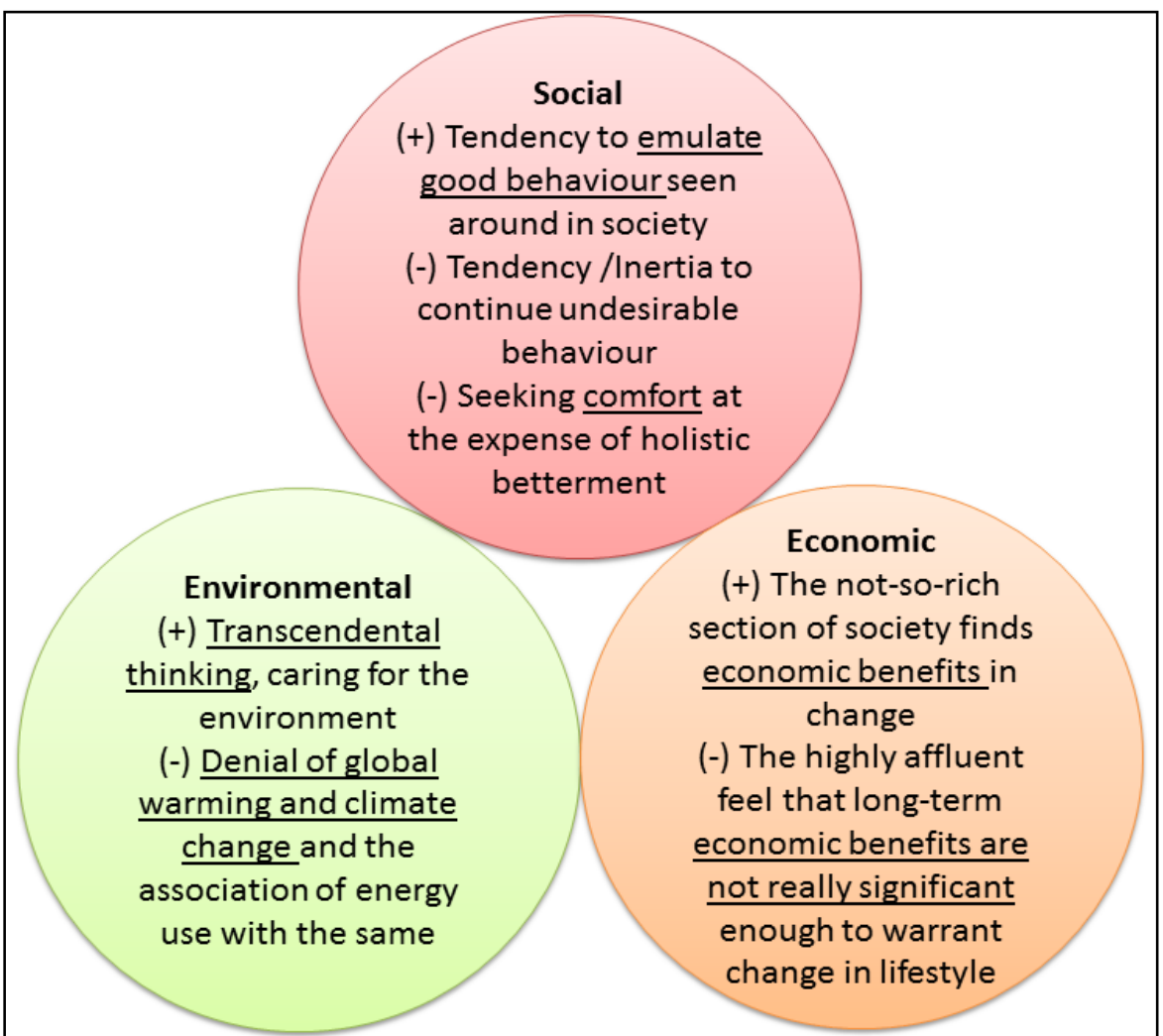

Figure 1. Human behaviour in the context of household energy usage issues in relations to the three aspects of sustainable development (Kjeang et al., 2017)

In this article, the authors have first presented a comparative analysis and critique of selected recently-published surveys related to energy use in households, from around the world, before applying the sustainability-thinking paradigm to their own regional survey of single-family households (detached houses and row houses) carried out in Karlstad (south-central Sweden), to obtain insights into user attitudes and preferences - categorised into the three dimensions of sustainability - when it comes to energy usage or decision-making with regard to retrofits or new energy-using / energysaving installations in households. The authors are of the opinion that this study will provide useful insights to researchers in this field, and contribute to the body of methodological knowledge especially. It will also open up a new way of thinking about the heterogeniety of energy users (which needs to be respected), for decision-makers and energy-advisers, who could subsquently strengthen their interaction and communication with them.

\section{Literature Review and Analysis}

The focus of this section is on selected published results of energy-use surveys from around the world. In order to narrow down the scope, the authors limit themselves to some publications from 2018. Further, the geographical span is widened in order to include countries (over 40) from different continents and also at different levels of socio-economic development. The goals and scopes of the publications reviewed are diverse. The publications have been categorised to zoom in from the non-European global to the Scandinavian, the last one also being the category to which this current article would belong. All papers reviewed were accessed and downloaded through Scopus; the journals in question being subscribed to, by the library at Karlstad University (Sweden) and/or the Norwegian University of Science and Technology (Trondheim), where one of the authors (Venkatesh) was a guest while working on this paper. The diversity of the focus/goal adopted by researchers is clear from the list in Table 1.

The survey conducted for this article is an addition to the body of knowledge which has been created in literature by researchers so far. The case studies reviewed form a very small subset of this vast body of knowledge which keeps growing at a steady pace. The knowledge of user behaviours and attitudes with respect to consumption of energy or resources in general, for that matter, is verily power in the hands of decision-makers which can be wielded responsibly and wisely, to ensure sustainable development in the years ahead. It helps to find answers to the question - Is it more effective to promote energy saving through emphasizing how this aligns with the selfinterest of the energy user, or with our shared interests in a better environment? 
Table 1. Summary of the literature review

\begin{tabular}{|c|c|c|c|}
\hline Publication & $\begin{array}{l}\text { Case study } \\
\text { region/country }\end{array}$ & Sample size & Goal / Focus \\
\hline $\begin{array}{l}\text { Al Qadi et al. } \\
\text { (2018) }\end{array}$ & Palestine (Hebron) & 322 & $\begin{array}{l}\text { Ridge Regression Analysis in the modelling of the influence } \\
\text { of many factors on the consumption of space heating en- } \\
\text { ergy in households }\end{array}$ \\
\hline $\begin{array}{l}\text { Amoah et al. } \\
(2018)\end{array}$ & $\begin{array}{l}\text { Ghana (Greater Accra } \\
\text { Region) }\end{array}$ & 1650 & $\begin{array}{l}\text { Economic-environmental analysis of installing energy- } \\
\text { saving light bulbs in households }\end{array}$ \\
\hline $\begin{array}{l}\text { Barthelmes et al. } \\
\text { (2018) }\end{array}$ & Denmark & $\begin{array}{l}9640 \text { indi- } \\
\text { viduals in } \\
4679 \text { house- } \\
\text { holds }\end{array}$ & $\begin{array}{l}\text { Survey to record daily time use for } 10 \text { defined daily activi- } \\
\text { ties for the sample, and then relate the same to correspond- } \\
\text { ing energy use }\end{array}$ \\
\hline $\begin{array}{l}\text { Benka-Coker et } \\
\text { al. (2018) }\end{array}$ & $\begin{array}{l}\text { Ethiopia (Addis Ab- } \\
\text { aba) }\end{array}$ & 50 women & $\begin{array}{l}\text { Survey to determine the acceptance and potential for scale- } \\
\text { up of bio-ethanol stoves for cooking in Ethiopian house- } \\
\text { holds }\end{array}$ \\
\hline $\begin{array}{l}\text { Gould et al. } \\
(2018)\end{array}$ & $\begin{array}{l}\text { India (six north-Indian } \\
\text { States) }\end{array}$ & 8568 & $\begin{array}{l}\text { Survey to determine the strengths, weaknesses, opportuni- } \\
\text { ties and threats for the adoption and use of LPG as cooking } \\
\text { fuel in rural Indian households. }\end{array}$ \\
\hline Jia et al. (2018) & China (urban Beijing) & $\begin{array}{l}569 \text { whittled } \\
\text { down even- } \\
\text { tually to } 311\end{array}$ & $\begin{array}{l}\text { Survey to understand public attitudes to energy-saving } \\
\text { measures in households }\end{array}$ \\
\hline $\begin{array}{l}\begin{array}{l}\text { Karytsas et al. } \\
(2018)\end{array} \\
\end{array}$ & Greece & 533 & $\begin{array}{l}\text { Survey to determine awareness about and the intention to } \\
\text { adopt ground-source heat pumps by households }\end{array}$ \\
\hline Kim et al (2018). & South Korea & 2250 & $\begin{array}{l}\text { Survey to study the factors influencing energy consump- } \\
\text { tion in the lowest- } 20 \% \text { and the highest- } 20 \% \text { of households } \\
\text { in Korea. }\end{array}$ \\
\hline $\begin{array}{l}\text { Klepacka et al. } \\
(2018)\end{array}$ & $\begin{array}{l}\text { Poland (Mozowiecke } \\
\text { Voivodship region) }\end{array}$ & 123 & $\begin{array}{l}\text { Survey to find out why households in rural Poland decide to } \\
\text { participate in the EU-funded solar thermal collectors sub- } \\
\text { sidy programme }\end{array}$ \\
\hline $\begin{array}{l}\text { Matos et al. } \\
(2018)\end{array}$ & $\begin{array}{l}\text { Portugal (Vila } \\
\text { County) }\end{array}$ & $\begin{array}{l}245(110 \text { ur- } \\
\text { ban }+135 \text { ru- } \\
\text { ral) }\end{array}$ & $\begin{array}{l}\text { Survey to study the influence of different factors affecting } \\
\text { household energy use in rural and urban Portugal }\end{array}$ \\
\hline $\begin{array}{l}\text { Matosovic et al. } \\
\text { (2018) }\end{array}$ & Croatia & 872 & $\begin{array}{l}\text { Survey of households to gather information about invest- } \\
\text { ment choices for energy-efficiency improvement and } \\
\text { modelling cost minimization and energy saving optimisa- } \\
\text { tion. }\end{array}$ \\
\hline $\begin{array}{l}\text { Nakano, R., et al. } \\
(2018)\end{array}$ & Bogor (Indonesia) & 600 & $\begin{array}{l}\text { Determinants - demographic, socio-economic, informa- } \\
\text { tional and participatory - of energy-saving behaviour in } \\
\text { households, with focus on willingness to use LED lighting }\end{array}$ \\
\hline $\begin{array}{l}\text { Nakano, S., et al. } \\
(2018)\end{array}$ & $\begin{array}{l}\text { Japan (Tokyo, Nagoya } \\
\text { and Kansai) }\end{array}$ & 619 & $\begin{array}{l}\text { Survey to determine factors which affect people's choices } \\
\text { of energy-efficient homes }\end{array}$ \\
\hline Palm (2018) & Sweden & 58 & $\begin{array}{l}\text { Interview to study the potentials of and barriers of adoption } \\
\text { of solar photovoltaics in Swedish households }\end{array}$ \\
\hline $\begin{array}{l}\text { Rahut et al. } \\
(2018)\end{array}$ & $\begin{array}{l}\text { East Africa (Ethiopia, } \\
\text { Tanzania and Uganda) }\end{array}$ & $\begin{array}{l}5262 \text { in Ethi- } \\
\text { opia } \\
5014 \text { in Tan- } \\
\text { zania } \\
3123 \text { in } \\
\text { Uganda }\end{array}$ & $\begin{array}{l}\text { Survey to determine the potential for adoption of solar en- } \\
\text { ergy by East African households }\end{array}$ \\
\hline $\begin{array}{l}\text { Shahmohammadi, } \\
\text { et al. (2018) }\end{array}$ & $\begin{array}{l}\text { Pan-European (Poland, } \\
\text { Greece, Romania, Bul- } \\
\text { garia, Czech Republic, } \\
\text { Germany, Ireland, UK, } \\
\text { Turkey, Hungary, } \\
\text { Netherlands, Portugal, } \\
\text { Slovakia, Italy, Spain, } \\
\text { Austria, Denmark, } \\
\text { Belgium, Finland, } \\
\text { Switzerland, France, } \\
\text { Sweden, Norway) }\end{array}$ & $\begin{array}{l}100 \text { UK } \\
\text { households } \\
\text { ( } 4741 \text { Euro- } \\
\text { pean house- } \\
\text { holds from } \\
23 \text { countries } \\
\text { as back- } \\
\text { ground data) }\end{array}$ & $\begin{array}{l}\text { Survey to understand the influence of consumer behaviour } \\
\text { and machine-related parameters in energy consumption and } \\
\text { life-cycle environmental impacts due to laundry washing } \\
\text { in households }\end{array}$ \\
\hline Thøgersen (2018) & $\begin{array}{l}\text { Pan-European } \\
\text { (Germany, Denmark, } \\
\text { Spain, Finland, France, } \\
\text { Hungary, Italy, Neth- } \\
\text { erlands, Poland, UK) }\end{array}$ & $\begin{array}{l}3200 @ 320 \\
\text { from each } \\
\text { country }\end{array}$ & $\begin{array}{l}\text { Survey to study variations (if any) on impacts of frugality } \\
\text { and environmental consciousness on energy-saving be- } \\
\text { haviour in European households }\end{array}$ \\
\hline
\end{tabular}




\begin{tabular}{|l|l|l|l|}
\hline Publication & $\begin{array}{l}\text { Case study } \\
\text { region/country }\end{array}$ & Sample size & Goal / Focus \\
\hline $\begin{array}{l}\text { Wemyss et al. } \\
(2018)\end{array}$ & Switzerland & 108 & $\begin{array}{l}\text { Survey to study the effect of a gamified mobile application } \\
\text { connected to the smart meters of households, on behaviour } \\
\text { change with regard to energy-saving }\end{array}$ \\
\hline
\end{tabular}

\subsection{Non-European surveys}

Al Qadi et al. (2018), in a survey conducted in Hebron (West Bank, Palestine), adopted a statistical approach, to study 17 socio-economic and physical parameters influencing the consumption of space heating in households, categorised them into environmental, building and system-related and occupants' behaviour, in addition to macroeconomic factors like energy policy and fuel prices. A bi-modal approach - web-based and handling out hard-copy questionnaires was adopted to gather data, and the responses accounted for 80.5 and $19.5 \%$ percentage of the total, respectively. These authors strongly recommend an optimisation of the existing energy consumption (which is largely fossil-based), before planning for the incorporation of renewable energy in the mix.

In a Ghanaian case study, Amoah et al. (2018) identified environmental consciousness, education and household income as important factors in explaining the choice of buying energy-saving light bulbs in the Greater Accra Region. These authors have defined environmental consciousness as the degree of local or global environmental knowledge acquired by an individual, household or society that informs their environmental behaviour (external) or attitude (internal). Environmental awareness in combination with an understanding of life-cycle costs, will most likely enable skeptics to take the leap to installing energy-saving bulbs by not considering the initial higher cost as a deterrent. A survey with a similar focus was conducted in Bogor (Indonesia) by Nakano R et al. (2018), in which the national efficiency labelling program and engagement of households in environment-related activities were shown to be effective energy-saving policy instruments. These authors are also of the firm belief that creating awareness about one's energy consumption is a necessary but not a sufficient condition to induce energy-saving behaviour among households in Indonesia.

If the focus of Amoah et al. (2018) and Nakano R et al. (2018) was on energy-saving lighting in households with a high initial cost but lower operational expenses, Gould et al. (2018) have a niche focus in their paper - the use of Liquid Petroleum Gas (LPG) in cooking in rural north-Indian households. They consider LPG to be a clean cooking fuel despite concerns about contribution to global warming. Clean is interpreted by these authors from a more holistic perspective; with several social aspects also being factored in. Insights from that survey have led the authors to recommend further customer-centric surveybased studies, government interventions and infra- structure development in order to enable LPG to replace a greater chunk of solid fuels which are being currently used, while acknowledging the fact that total displacement will not be possible. Cooking fuel is the subject of interest in the Ethiopian case study in Benka-Coker et al. (2018), but it is bio-ethanol from molasses, and not LPG from petroleum. The driving factors are similar to the ones which have motivated the adoption of LPG in rural India (Gould et al., 2018). The meagre degree of industrialization in Ethiopia, makes the household sector the largest energy consumer (93\% of the total) and thereby the focus of research in the years ahead. As observed by Benka-Coker et al. (2018), the factors motivating adoption of the ethanol stove ranged from being free (economic), healthier (socio-environmental), safer (social) and quicker (functional); while the barriers for widespread use include low awareness of bioethanol as a cooking fuel and the high cost of both bio-ethanol and the stoves. Interestingly, the use of charcoal stoves to make coffee is a socio-cultural tradition, conflicting with other sustainability goals. Ethiopia figures again alongwith Tanzania and Uganda in Rahut et al. (2018) who have investigated the potential for solar PV in households. They found, in general, that acceptance of solar PV was essentially a rural remote households phenomenon, with richer rural households, with children and/or a higher number of adult males having a greater proclivity to invest in solar PV. Contrary to what is usually observed in the western world, households headed by males showed a greater interest in doing so, vis-à-vis those headed by females in general.

After the Fukushima Daiichi nuclear disaster in Japan in 2011, the Japanese Government has been focusing more strongly on improving energy efficiency in society and the economy. By $2030,23 \%$ of the targeted reduction in energy use (with respect to the Business-As-Usual scenario as the baseline), is to come from households (Nakano, S et al., 2018). The authors are of the view that understanding people's behaviour, perceptions, attitudes and motivations is the first step and enlightening them based on this understanding about the benefits of new energysaving technologies is a subsequent step. These, they say, are pre-requisites if top-down policy-making has to yield sustainable, long-term benefits. One of the findings from the survey that environmental considerations (environmental aspect) without taking the costs into consideration (economic aspect) may not positively affect the satisfaction (socio-psychological aspect) of living in an energy-efficient home. China became the largest energy consumer in the world, in 2015, as noted by Jia et al. (2018). In this 
most populated country in the world, obviously, households account for a sizable portion of the energy usage pie. In this Chinese study, the authors have identified a range of attitudes and perceptions among the sample set studied, but have stopped short of using the information to determine the proclivities of the respondents to the three dimensions of sustainability. They found that a typical person who would be keen on purchasing energy-efficient appliances is an older, well-educated, high-earning man living in a detached house. This is an interesting finding and may contradict findings from surveys conducted in the western world. Kim et al. (2018) have found that middle-aged, better-educated, self-employed, highearning urban Koreans residing in large houses tend to consume more energy. The mean monthly energy consumption for the fifth quintile is about $106 \mathrm{kWh}$ greater than that for the first quintile; with the maximum value for the first being quite close to the minimum value for the fifth. These authors have thereby recommended the expansion of the supply of energyefficient air-conditioners in order to reduce the cooling energy demand in larger Korean households.

\subsection{European surveys}

Shahmohammadi et al. (2018) is a pan-European survey which has focused on laundry washing in households which, as the authors have observed, accounts for the largest share of domestic energy consumption in some parts of the world. In the EU for that matter, in the period 2012-2017, it has accounted for $22 \%$ of the total final energy consumption (Matosovic et al., 2018). They have estimated a possible maximum reduction in greenhouse gas (GHG) emissions equal to 5.9 million tonnes of $\mathrm{CO}_{2}$-eq per year, if users in Europe could switch all their washes (34.3 billion per year, estimated) to $30^{\circ} \mathrm{C}$ or lower. One could perhaps expect this behaviour change at least from all the environmentally-aware users; and depending upon what percentage of the European population can be categorized thus, a corresponding decrease in GHG emissions.

In Croatia, households account for $31 \%$ of the final energy consumption - the highest in the EU. This makes Matosovic et al. (2018) a very important contribution to energy planning literature. Croatia is a part of the EU, but vis-à-vis the northern and western European countries, is at a lower level of economic development. Thereby, the economic aspect of energy-efficiency improvement in households, is paramount in Croatian society, with users tending to think predominantly in monetary terms. The authors have stressed on the need for government subsidies to reduce energy usage in households, but have also observed that as the subsidy amounts awarded tend to rise, the cost per unit energy saved also tends to increase. This, they opine, can be overcome by tuning the amount of subsides awarded, on the basis of the energy saving achievable in households at different economic strata. Greece $(29 \%)$ is not far from
Croatia when it comes to the residential sector's share in the total national energy usage; and the fact that fossil fuels dominate the energy mix in the country, prioritizes energy saving in households, as a key policy issue (Karytsas, et al., 2018). The researchers identified about 27 factors affecting residential heating system selection in Greek households. Among those who intended to install a ground-source heat pump in their houses, but could not do so, $55 \%$ said that they were hindered by the need for consensus among the residents of apartment buildings, while $47 \%$ cited the high initial cost as a hurdle.

Solar thermal collectors to supply the heat demand in households, can replace natural gas and electricheating from households. As fossil fuel use is predominant in Poland, an increase in the rate of adoption of subsidised solar collectors, as argued in Klepacka et al. (2018), will contribute effectively to a truncation in the GHG footprint of Polish households, while improving air quality, reducing energy bills and also serving as a showcase of renewable energy for the non-adopters. The survey showed that convenience of use - not having to use coal, handle ashes and encounter smoke pollution within the households - and expected lower energy costs postinstallation were considered very important reasons for choosing to install a solar collector by $74 \%$ and $70 \%$ of the respondents, respectively.

Thøgersen (2018), in a survey conducted across 10 European countries (including the three Scandinavian countries), have identified two self-identities as being driving factors for energy-saving in households - being environment-friendly (biospheric values) and being frugal (egoistic values). He also believes that either of these can motivate energy-saving, depending on situational activation, while referring to prior publications which support this statement. Swiss researchers, in a 2-year experiment, tested the durability of household behaviour changes brought about by a gamified mobile application Social Power - a year after the intervention had ended (Wemyss et al., 2018). The power of information, feedback, reminders, notifications, counterconditioning, stimulus control and community-based strategies in improving energy-use behaviour ought not to be underestimated. In this particular study, immediately after the intervention, a significant improvement in energy savings was observed (average of 7-9\%, with a maximum of close to $40 \%$ ). But after a year, the tendency to relapse into the earlier habitual behaviour was also witnessed.

\subsubsection{Scandinavian surveys}

While Klepacka et al. (2018) deals with solar heating in rural Polish households, Palm (2018) has focused on the barriers to and opportunities for the installation of solar PV systems (for electricity generation) on rooftops of households in Sweden. Like Nakano R. et al. (2018), they have stressed on the development of easily accessible information like labelling 
systems for PV panels and mandatory certification for installation firms, to increase the number of prosumer households in the country. Palm (2018) detected diverse attitudes even among the relativelysmall sample set of 58 households.

Barthelmes et al. (2018) contends that modelling energy-related household human activities - cooking, washing dishes, washing clothes, bathing (hot water), watching TV, using IT devices, having lights/fans and space heating on - throughout the day is a crucial task which will go a long way in reducing the gap between real and predicted energy usage. In Shahmohammadi et al. (2018), the three Scandinavian countries were also a part of the survey. The median share of the actual washing phase in the laundry life-cycle to GHG emissions, was $70 \%$ for Denmark vis-à-vis $30 \%$ and $25 \%$ for Sweden and Norway respectively. The authors reckoned with the respective national electricity mixes for these three countries, instead of the Nordic mix for all three of them. With respect to truncation of GHG emissions, this indicates a greater potential in Danish households, with behaviour change. Thøgersen (2018) showed that there is no direct effect of environmental self-identity and frugality (attitudes) on energy-saving behaviour in Danish households.

\section{Methodology of the survey}

\subsection{Questionnaire}

A list of questions was drawn up in English and Swedish. The questionnaire has been presented in Table 2. Information about the respondent - gender, age, education, income, family size etc., opinions about household energy consumption and energy advising, were sought through a set of 20 questions in all. One of the prime qualifications for a respondent was home-ownership. Tenants obviously do not have the incentive to invest in durable energysaving retrofits in homes in which they may not stay for more than a few years. If a recipient did not own the home he/she was dwelling in, he/she obviously would refrain from responding.

Table 2. The questions which were sent out to prospective respondents on Survey Monkey

1. When was your house built?

2. Was remodelling done later? If yes, when?

3. How long have you owned the house?

4. How is the house heated currently? Multiple answers are possible.

a) Electricity b) Electricity and air-source heat pump c) District heating d) Firewood e) Ground source heat pump f) Pellets g) Other alternatives

5. Have you made any purchases / investments in the last three years to save energy?

a) Yes
b) No
c) Do not know
6. Are you planning to do it in the near future?
a) Yes
b) No
c) Do not know

7. If yes, what have you planned to do? Tick for one or more cases.

a) Changing windows

b) Additional insulation of attic or wall

c) Changing the heating system

d) New lighting

e) Bigger remodelling/conversion (eg. kitchen, bathroom, etc.)

f) Something else

8. On a scale of 0 to 4 , how important do you think these factors are, when you have to make decisions on optimizing energy consumption in your home? $(0$ corresponds to not important at all; 1 - not completely unimportant; 2 - quite important; 3 -important; 4 very important)

a) Investment cost for changes to be made

b) Lifecycle cost of all forms of changes

c) Profitability - How quickly do I get back my investment

d) Environmental benefits in terms of climate

e) Reduced emissions to the air in my vicin

f) Reduction in use of natural resources

g) I am inspired by what neighbours and friends do in their homes

h) Unchanged or improved comfort

i) Aesthetic aspects

9. Have you chosen eco-labelled electricity?

a) Yes

b) No

c) Do not know

10. The municipality or the energy company in your city offers a collaborative project in your own villa area to assist you as a property owner to supplement the attic insulation and/or change windows in a joint procurement the coming summer. Does this sound interesting to you? Would you like to avail of such an offer?

a) Yes, when can we start?

b) Perhaps, but first I want to talk with my neighbours about this

c) No thanks, I can manage it myself

11. Do you often think that you would like or should fix things in the house that can affect energy use?

a) Yes

b) No

c) Do not know

12. If yes, why are you thinking of these issues? Choose one of the three following options:

a) It feels like everyone is doing these things today

b) For environmental and climate reasons

c) To lighten my energy bill

13. Have you installed any new heating system in the last five years? If yes, who took the decision to install a new heating system? 

a) I did
b) My partner
c) Both together
d) Another person

14. Do you think your efforts to save energy in the house contribute to the reduction of carbon dioxide emissions in Sweden?
a) Yes
b) Maybe
c) No. The contribution is very small

15. Where do you live?

a) In a rural area or in a city (outside metropolitan areas) with less than 5,000 inhabitants

b) In a city (outside metropolitan areas) with 5,000 $-24,999$ residents

c) In a city (outside metropolitan areas) with 25,000 - 175,000 inhabitants

d) In a metropolitan area (like Greater Stockholm, Greater Gothenburg, Greater Malmö)

16. When were you born?

17. Would you describe yourself as:

a) Woman

b) Man

c) Other

18. What is the household's highest education?

a) Primary school

b) Secondary school

c) High school

d) University or college education

19. How many people live in the household, including yourself? Of these, how many are less than 18 years old?

20. What is your household's approximate annual income?

a) Less than $200,000 \mathrm{SEK}$

b) $200,000-500,000 \mathrm{SEK}$

c) More than $500,000 \mathrm{SEK}$

21. Any additional comments?

The Survey Monkey web-platform was used to communicate with employees with Karlstad University in Sweden. Their e-mail addresses were obtained from the Communications Department of the University (Ganrot and Emamuelsson, 2017), and the questionnaire was sent out in the second half of year-2017. The responses were collected over a period of 4 weeks. In order to diversify the sample set, one of the authors (Kjeang) contacted households in a small community on the outskirts of the city of Karlstad, to collect responses to the same questions which were posed to the employees at Karlstad University. In all, about 300 households were contacted. The respondents were promised that their identities would not be revealed. The responses were then systematically compiled in spreadsheets for further analysis.

\subsection{Analysis of the three dimensions of sustainability}

Three criteria were selected for each of the three sustainability dimensions - social, economic and environmental (Refer question 8, in which the criteria have been presented in boldtype, in the survey questionnare in Table 1). The authors acknowledge the fact that the choice of criteria and the actual formatting of the same (the precise words used to describe them) may influence the values respondents assign to them. The environmental criteria encompass the use of resources as well as global and local environmental impacts. Local impacts are the in my backyard types, which directly affects the energy-user, while global impacts are ones which users who are environmentally unaware dismiss as those which they cannot influence much and so do not bother about. While initial investment, operational expenses and profitability (in this case, related to energy saving vis-à-vis the status quo which users would wish to alter) are all related to each other, often they may not be valued alike, even by respondents who are aware of this interrelationship. The social dimension includes comfort (function), aesthetics (form) and the willingness to emulate others in society.

To the best of the authors' knowledge, the criteria chosen are extremely relevant to energyconsumption-related decisions taken by homeowners in Sweden. Respondents were asked to rate the importance of each criterion while making decisions regarding improvement of energy efficiency in their households on a Likert scale of 0 to 4 , with a linearly increasing degree of importance. Assigning equal weights to all the nine criteria, the numbers assigned to each of the three dimensions were added up, and represented as a fraction (or percentage) of the sum of all the nine, in order to get overall weighting factors for each respondent for the three dimensions (Refer to equations below).

For respondent $\mathrm{A}$, let the numbers assigned to the nine criteria be as under:

$\mathrm{X}_{\mathrm{A}, 1, \mathrm{~s},}, \mathrm{X}_{\mathrm{A}, 2, \mathrm{~s}}, \mathrm{X}_{\mathrm{A}, 3, \mathrm{~s}}, \mathrm{X}_{\mathrm{A}, 1, \mathrm{ec},} \mathrm{X}_{\mathrm{A}, 2, \mathrm{ec}}, \mathrm{X}_{\mathrm{A}, 3, \mathrm{ec}} \mathrm{X}_{\mathrm{A}, 1, \mathrm{e}}, \mathrm{X}_{\mathrm{A}, 2, \mathrm{e}}$, $\mathrm{X}_{\mathrm{A}, 3, \mathrm{e}}$

The suffixes - s, ec and e - stand for social, economic and environmental respectively. The sum of the numbers for these three dimensions are then: $\sum_{n=1}^{3} X_{\mathrm{A}, \mathrm{n}, \mathrm{s}}=\mathrm{X}_{\mathrm{A}, \mathrm{tot}, \mathrm{s}} \quad$ Equation 1 $\sum_{n=1}^{3} X_{\mathrm{A}, \mathrm{n}, \mathrm{ec}}=\mathrm{X}_{\mathrm{A}, \mathrm{tot}, \mathrm{ec}} \quad$ Equation 2 $\sum_{n=1}^{3} X_{\mathrm{A}, \mathrm{n}, \mathrm{e}}=\mathrm{X}_{\mathrm{A}, \text { tot,e }} \quad$ Equation 3 The weighting factors then are calculated simply as: $\mathrm{W}_{\mathrm{s}, \mathrm{A}}=\mathrm{X}_{\mathrm{A}, \text { tot } \mathrm{s}} /\left(\mathrm{X}_{\mathrm{A}, \text { tot,e+ }} \mathrm{X}_{\mathrm{A}, \mathrm{tot}, \mathrm{ec}+}+\mathrm{X}_{\mathrm{A}, \text { tot } \mathrm{s}}\right)_{\text {Equation } 4}$ $\mathrm{W}_{\mathrm{ec}, \mathrm{A}}=\mathrm{X}_{\mathrm{A}, \mathrm{tot}, \mathrm{ec}} /\left(\mathrm{X}_{\mathrm{A}, \text { tot,e }}+\mathrm{X}_{\mathrm{A}, \mathrm{tot}, \mathrm{ec}}+\mathrm{X}_{\mathrm{A}, \mathrm{tot}, \mathrm{s}}\right) \quad$ Equation 5 $\mathrm{W}_{\mathrm{e}, \mathrm{A}}=\mathrm{X}_{\mathrm{A}, \text { tot,e }} /\left(\mathrm{X}_{\mathrm{A}, \text { tot,e }}+\mathrm{X}_{\mathrm{A}, \text { tot,ec }}+\mathrm{X}_{\mathrm{A}, \mathrm{tot}, \mathrm{s}}\right) \quad$ Equation 6 Thus, the weightages assigned to the social, economic and environmental dimensions are relative to each other, for each respondent. In other words, for instance, if a respondent assigns the value 2 to all the nine criteria, and thereby has a total of 6 for each dimension, he/she would have equal weightages - 
$33.3 \%$ each. On the other hand, if a respondent has a total of 8 for each dimension (with each of the subcriteria having any value $0,1,2,3,4)$, the weightages would still be $33.3 \%$ each. If a respondent did not assign any value to a criterion, it was assumed to be zero (not important to him/her at all); though here, the authors do acknowledge that this may have been oversight on the part of the respondent. However, if a respondent did not assign any value to all the nine criteria, that response was excluded from the analysis. After exclusion of the incomplete responses, the authors were left with a total of 286 complete and valid responses to work with.

\section{Survey results and discussions}

4.1. Background information about the respondents Most of the respondents (over $80 \%$ ) have a family income greater than 500,000 SEK per annum. A little less than one-third of the respondents live in 2member households, followed by almost the same proportion in 4-member households. Among the others, there is one 8-member household and four 6member ones. A significantly high percentage of the respondents $(90 \%)$ are university-educated, while relatively few have indicated the highest educationl qualification in the household as primary school or secondary school. The male-female ratio is approximately 9:8, with 18 more males than females (See Figure 6). As far as the ages are concerned, close to $50 \%$ are below 50 years of age (See Figure 2 ), with the youngest respondent stating her age as 28. The oldest in the sample set is also a female who is 89 years old. From the responses to Q15 in Table 2 , it was gathered that three respondents belong to big metropolitan cities, 74 dwell in the countryside, 129 live in non-metropolitan small cities with populations ranging between $25,000-175,000$ inhabitants (the city of Karlstad being one such), and the remaining live in smaller towns with populations less than 25,000. The ages of the houses (based on when they were first built) range from 3 years to over 300 years.

When asked if they thought whether their efforts to save energy in their households contribute to reducing the GHG footprint of Sweden, more than half of them answered in the affirmative. Interestingly, there were a little more than 30 respondents who did not think so. When one considers that the Swedish electricity mix has a very small carbon footprint (being dominated by hydropower and nuclear energy), these 30 respondents thought right. The others were not sure, but veered a bit towards the affirmative with a Perhaps. Over a hundred of them had not installed any new heating system in their households over the last five years (2013-2017, that is), while about 90 of them said that the decision to install a new heating system was a consensual one between the respondent and his/her partner. Among the 40 who stated that the decision was taken individually, there were more men than women, and relatively few staying in one-member households. Quite interestingly, there were a few respondents who said that they were not aware of whether they had chosen an electricity supplier who was providing them with eco-labelled electricity - revealing the need for providing information to consumers in general about the concept of eco-labelling of electricity. However, a majority of them answered in the affirmative.

A good majority (close to $60 \%$ ) of the respondents stated that they have been mulling over making changes to the energy-consuming systems/devices in their households of late. One-third of these are motivated by environmental concerns to do so, 2 of them are inspired by what they observe others doing in the neighbourhood, and the rest are driven by economic concerns to consider retrofits. The average number of years a respondent has owned his/her house is 16 years, with about $70 \%$ of them having owned theirs for 20 years or less. The 89 -year old female respondent has owned her house for 59 years.

\subsection{Analysis of the three dimensions}

Figure 3 presents the distribution of the dominance of the three dimensions of sustainability - social, economic and environmental - among the respondents. Over $42 \%$ have ranked the environmental dimension right on top, while about a third of them are guided more by the economic aspect. A smaller fraction (less than $10 \%$ ) lay more emphasis on the social aspect, vis-à-vis the economic and the environmental. It is also seen that 45 respondents have equiweighted two of the three dimensions. There are more economic-environmental equi-weightings compared to the socio-economic and the socio-environmental. On average, the economic dimension has got a weightage of $35.45 \%$; the environmental, $36.33 \%$ and the social, $28.22 \%$, indicating a marginal overall preference for environment-friendly decisions.

Table 3 presents information about the individual values assigned by the respondents to each of the nine criteria. Figure 4 shows the distribution of the weightages assigned to each of the three dimensions. There is one respondent who rates the environmental aspect very high at the expense of both the social and the economic. Likewise, there are two who have assigned a very high weightage to the economic aspect, at the expense of the other two. Over $44 \%$ of the respondents have assigned a weightage (indirectly, as determined by the methodology adopted for this survey by the authors) in the range of $30 \%-40 \%$ for the environmental aspect, while about $40 \%$ have chosen to put the economic aspect in that range. As far as the social aspect is concerned, most of the respondents (over 90\%) assign a weightage of less than $40 \%$ to it -119 of them put it in the $20 \%-30 \%$ range. This is a revelation. 


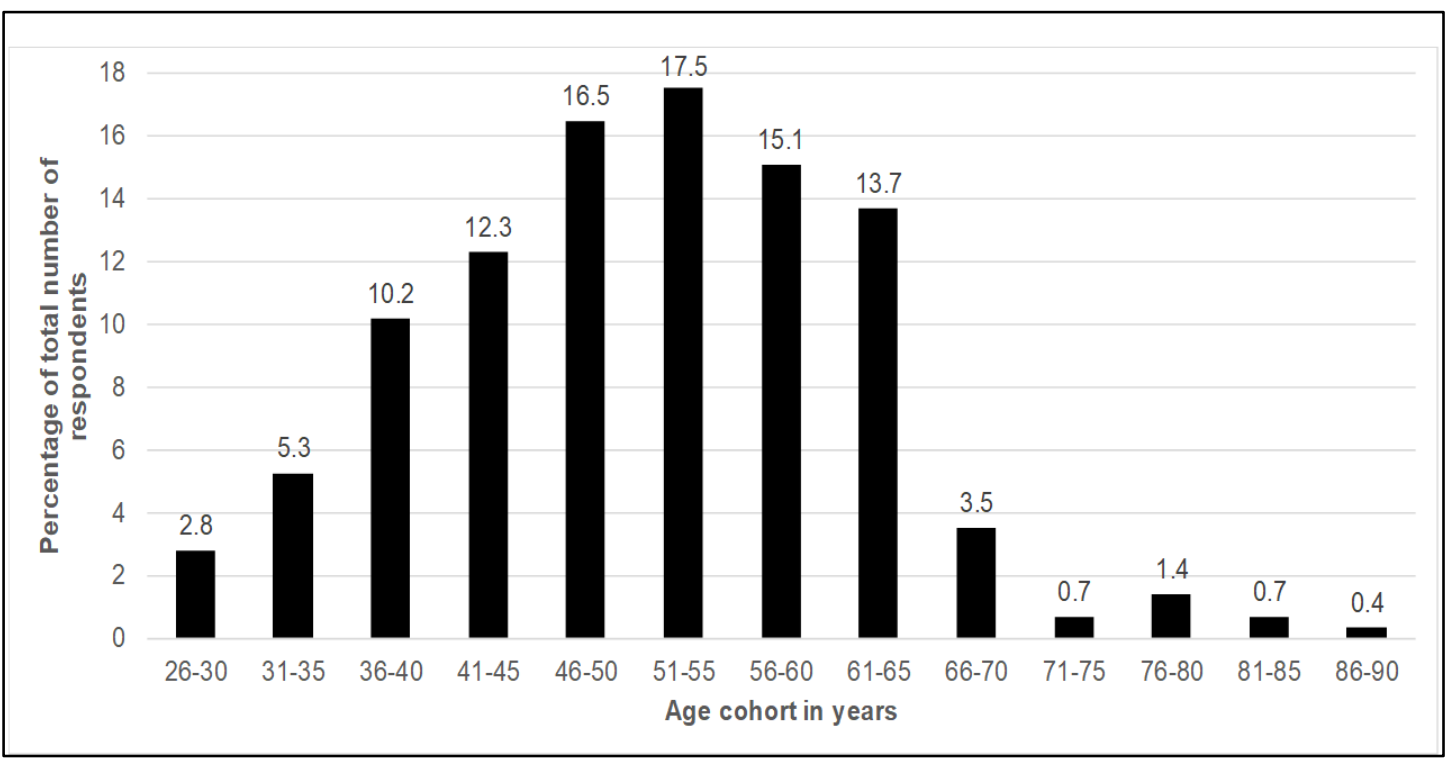

Figure 2. Age-cohorts and percentages of the total number of respondents in the survey

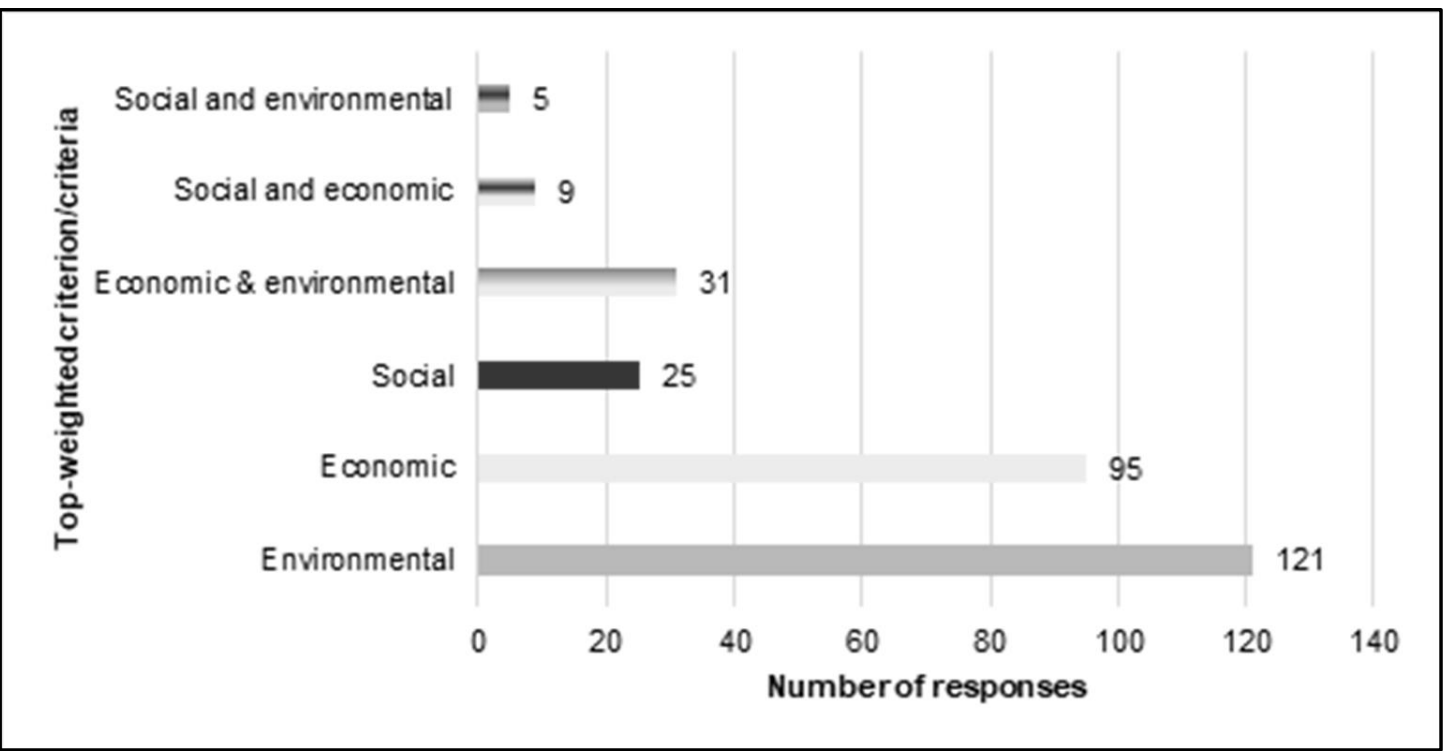

Figure 3. Distribution of the responses on the basis of the highest-weighted criterion

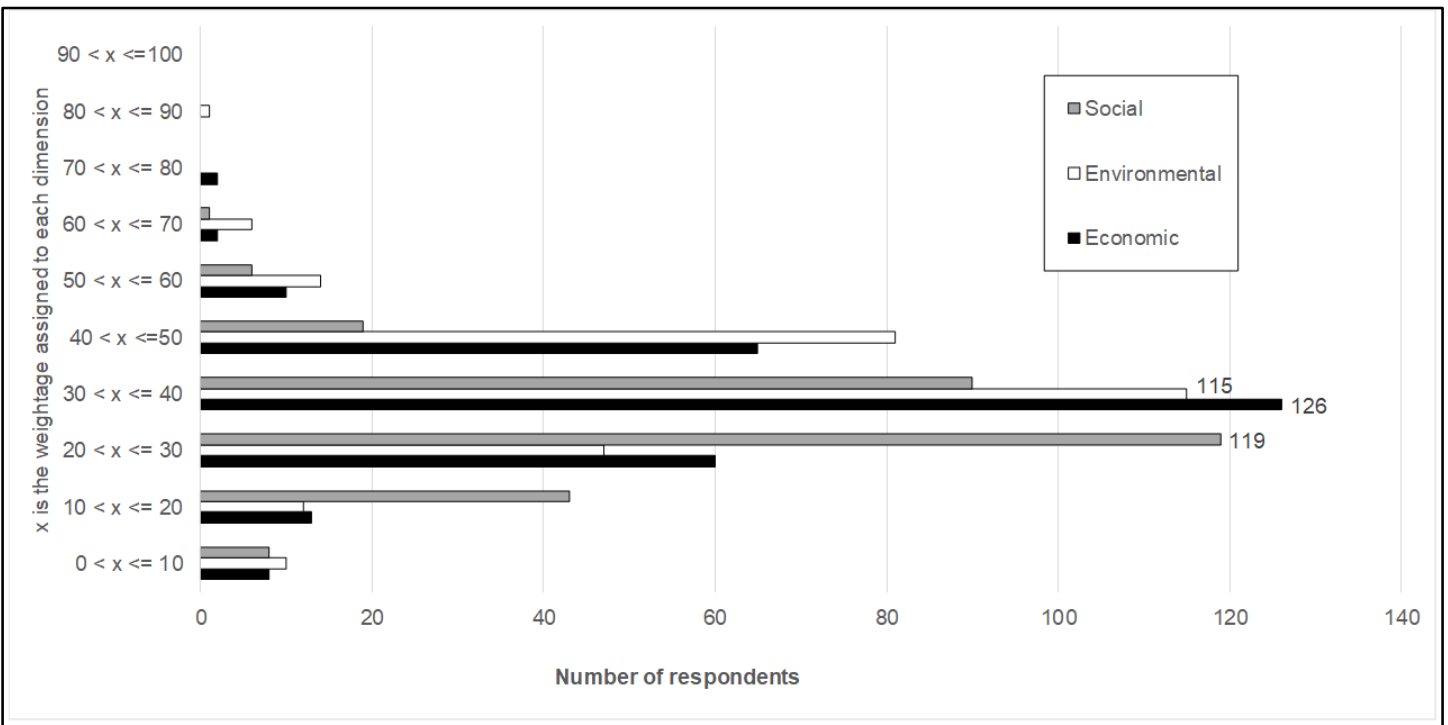

Figure 4. The spread of the weightages of the different dimensions 
Table 3. How the different criteria fared, among the 292 respondents (Refer Question No. 8 in Table 2 for the designations of the criteria)

\begin{tabular}{|c|c|c|c|c|c|c|c|c|}
\hline \multirow[t]{2}{*}{ Criteria } & \multirow{2}{*}{$\begin{array}{l}\text { Sum of all } \\
\text { values as- } \\
\text { signed }\end{array}$} & \multirow{2}{*}{$\begin{array}{l}\text { Average of all } \\
\text { values as- } \\
\text { signed }\end{array}$} & \multirow{2}{*}{$\begin{array}{c}\text { Standard devia- } \\
\text { tion of all val- } \\
\text { ues assigned }\end{array}$} & \multicolumn{5}{|c|}{$\begin{array}{l}\text { Total number of instances } \\
\text { (Scores on the } 0-4 \text { scale) }\end{array}$} \\
\hline & & & & 4 & 3 & 2 & 1 & 0 \\
\hline \multicolumn{9}{|c|}{ Economic dimension } \\
\hline a) & 815 & 2.78 & 1.00 & 78 & 117 & 63 & 24 & 10 \\
\hline b) & 770 & 2.63 & 0.96 & 56 & 127 & 70 & 23 & 16 \\
\hline c) & 659 & 2.25 & 1.08 & 38 & 92 & 85 & 59 & 18 \\
\hline Overall & 2244 & 2.55 & & & & & & \\
\hline \multicolumn{9}{|c|}{ Environmental dimension } \\
\hline d) & 778 & 2.66 & 1.06 & 62 & 124 & 65 & 26 & 15 \\
\hline e) & 731 & 2.49 & 1.11 & 53 & 113 & 71 & 37 & 18 \\
\hline f) & 803 & 2.74 & 1.07 & 75 & 118 & 60 & 27 & 12 \\
\hline Overall & 2312 & 2.63 & & & & & & \\
\hline \multicolumn{9}{|c|}{ Social dimension } \\
\hline g) & 327 & 1.12 & 1.11 & 7 & 37 & 46 & 95 & 107 \\
\hline h) & 803 & 2.74 & 0.90 & 59 & 131 & 75 & 22 & 5 \\
\hline i) & 604 & 2.06 & 1.12 & 25 & 95 & 71 & 76 & 25 \\
\hline Overall & 1734 & 1.97 & & & & & & \\
\hline
\end{tabular}

As one notices from Table 3 as well, the sum of the values assigned for the criterion $(\mathrm{g})$ - the tendency to keep up with and emulate what the neighbours do - is the least, with an average of just 1.12. Likewise, the respective average for the criterion (i) - aesthetics - is 2.06. However, Unchanged or improved comfort as a criterion has an average value of 2.74 , the second-highest along with criteria (f) - Reduction in the use of natural resources. This, one can say is a more practical concern, vis-à-vis aesthetics, a much greater focus on function compared to form. The highest average value is 2.78 for the very first criterion - Investment costs for changes to be made. It must be pointed out here that criterion (b) - Lifecycle costs, scores 2.63 on average (and ranks third); indicating a need for awareness to be created among home-owners in general, about thinking in terms of life-cycle costs. However, a look at Table 3 will show that this criterion (b) has still scored more $3 \mathrm{~s}$ and $2 \mathrm{~s}$ than criterion (a). Figure 5 shows that there is no definite correlation between age of the respondent, and the way the dimensions have been weighted. The last split bar in Figure 5 carries the same information which has been presented in Figure 3 above. Figure 6 shows that the percentage of men who weight the environmental aspect over the others, is almost the same as that of the women who do so, indicating a fair degree of uniformity as far as environmental awareness is concerned. Those who assign equal priority to the economic and the environmental aspects are relatively more than those do so for the other two combinations.

The alternatives which house-owners have at their disposal when it comes to the choice of space and water heating systems are numerous. The different options have different life-cycle costs, life-cycle environmental impacts and are valued differently when it comes to comfort and aesthetics. The alternatives seen on the X-axis in Figure 7 include air-source heat pump, ground-source heat pump, electric heating, district heating, pellets and wood. Others here encompass oil, solar heating etc.

From Table 3, one can see that the average scores for the criteria (d), (e) and (f) are in the range of 2.49 to 2.74 ; and the number of $3 \mathrm{~s}$ given to these three criteria are also within a relatively narrow range. This indicates to some extent that environmental awareness encompasses knowledge of natural resources depletion as well as local and global adverse effects of emissions of pollutants from anthropogenic activities. However, whether those who have assigned a high weightage to the environmental dimension, actually try to understand the life-cycle environmental impacts of the options available to them before making a decision, is not known. This needs to be investigated in further research.

\subsection{Discussions}

From Figure 7, it is seen that there are households which avail of multiple sources of space and water heating. This observation is similar to the one made in Al Qadi et al. (2018) for Hebron, but the difference is that in Hebron, the multiplicity is a hedge against electricity blackouts - with electric heaters being the dominant mode of space heating - and the risk of running out of certain types of fuels owing to poor infrastructure. It is also worth mentioning, en passant, here that the sample size and the modal shares of the responses received, for the survey carried out for this paper by the authors, are quite similar to those in Al Qadi et al. (2018), though the average number of members in a household is much greater in Hebron. In this survey, the authors have defined three criteria to represent environmental consciosuness and assumed the valuation thereof to be a reasaonably accurate estimate of the degree of pro-environmentalism. Here, it would be worth citing Amoah et al. (2018), who state that so far, literature has not been able to provide any cast-instone definition or measurement that is all-encom- 


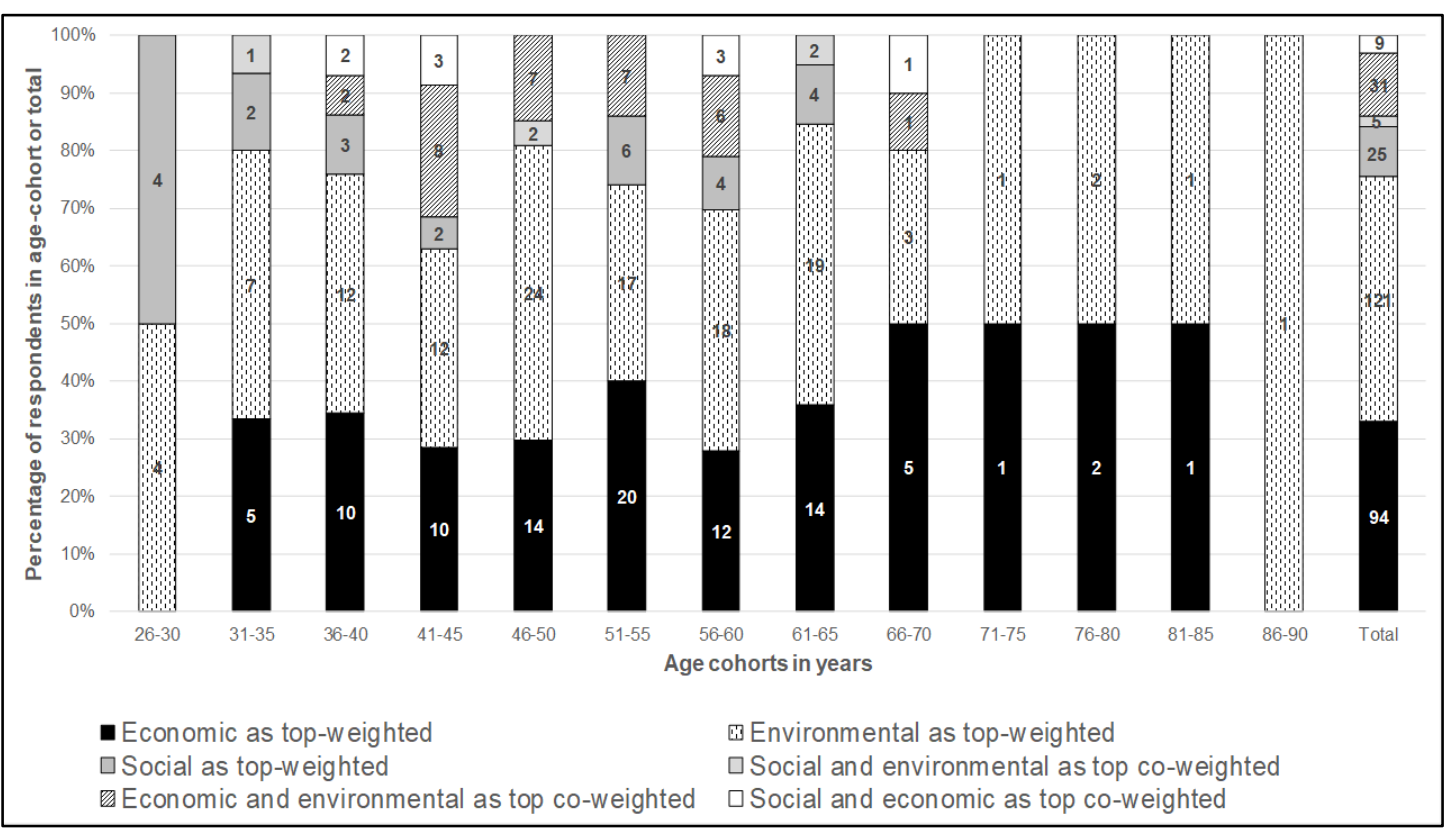

Figure 5. Distribution of the highest weighted/co-weighted dimensions, on the basis of age-cohorts - highest-weighted/coweighted criterion/criteria

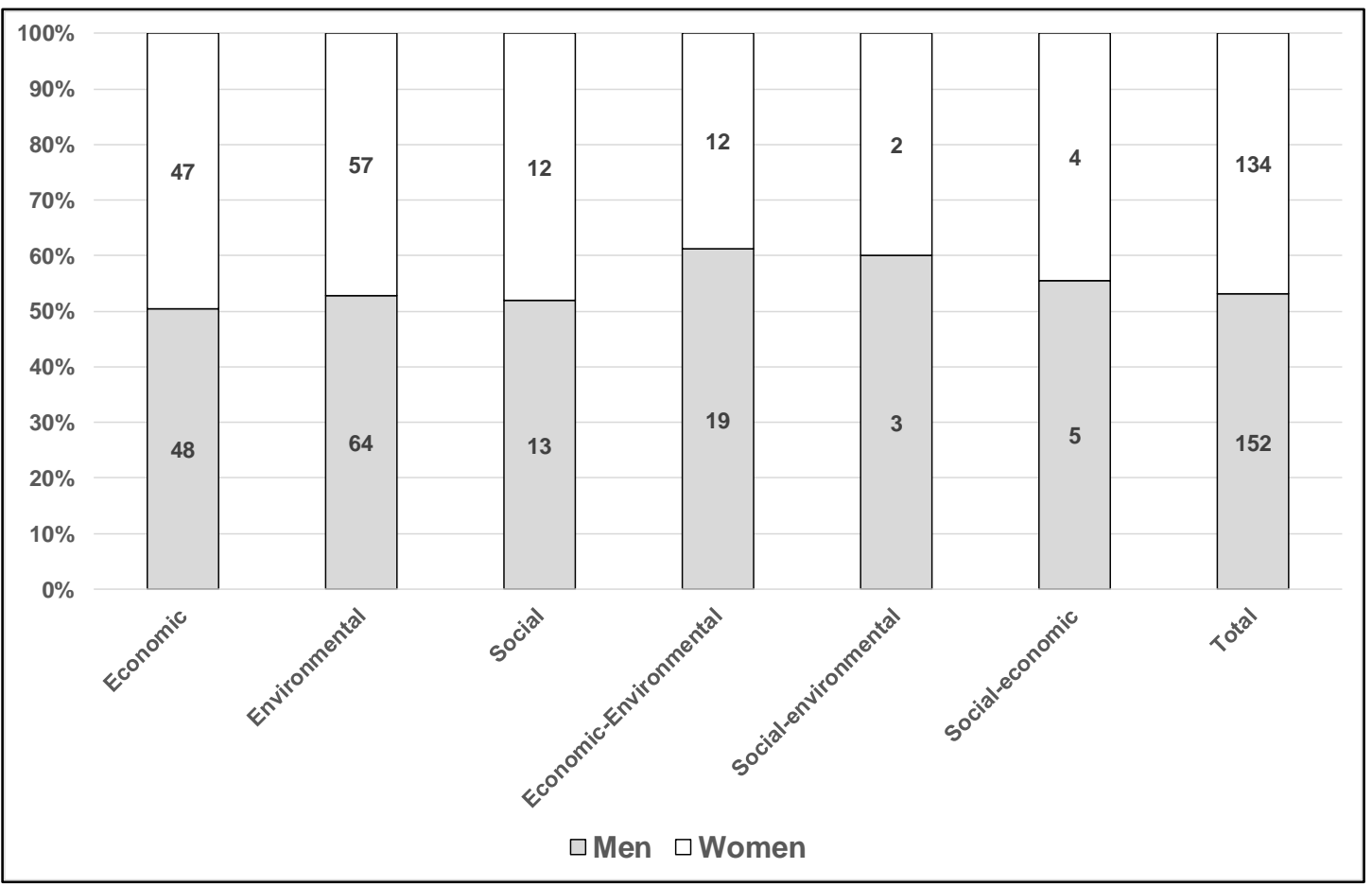

Figure 6. Gender-wise distribution of dominance of the dimensions

passing in explaining environmental consciousness. While the Karlstad survey showed that the average weightage assigned to the environmental dimension is the highest, the Croatian study by Matosovic et al. (2018) bases its study on the premise that users in this Mediterranean country tend to think predominantly in monetary terms. Interestingly, while the criterion $(\mathrm{g})$ in the present survey scored the least ( 1.12 on average), the tendency to be influenced by what is seen around in society, turns out to be a dom- inant factor among the Chinese residents surveyed by Jia et al. (2018), when it comes to closing windows to reduce heat loss. In Karytsas et al. (2018), the need for social consensus among the residents of apartment buildings turns out to be a deterrent among some of the respondents, who are willing but not able to install ground-source heat pumps.

An explicit categorisation into social, economic and environmental criteria (as the authors have done, in this survey) was not made in Gould et al. (2018) and 


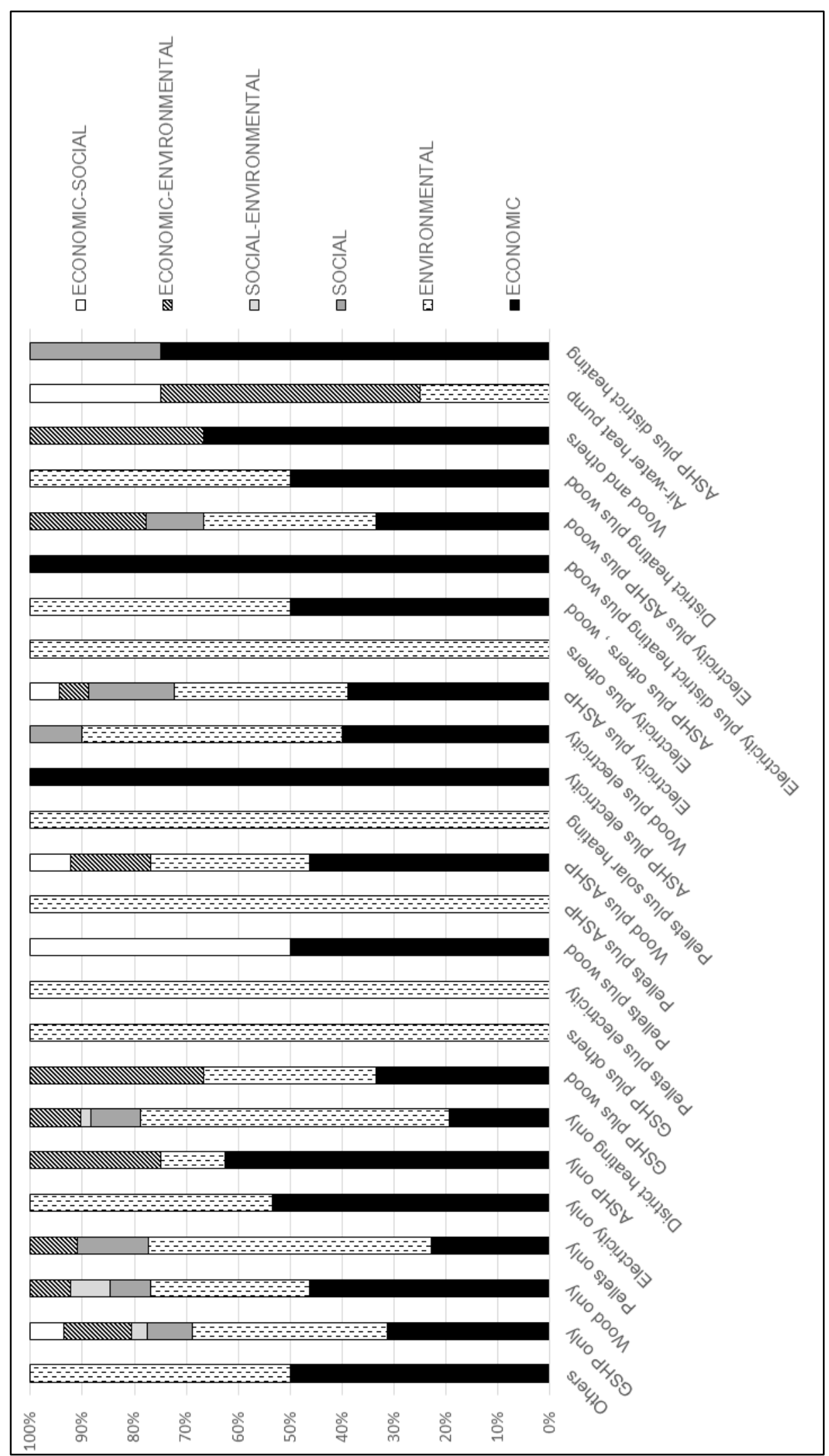

Figure 7. Shares of the top-weighted (co-weighted) criterion/criteria, for the different heating systems (or combinations of heating options) in vogue at the homes of the respondents

Jia et al. (2018), but one can identify these among the positive and negative perceptions gathered by the authors in their survey. Convenience (which also includes availability, accessibility and safety) figures 
as a social criterion, health issues due to household/community air pollution (closely related to the criterion (e) in Table 1 and Table 3) can be categorised as socio-environmental, and the installation cost and operation expenses - together, life-cycle cost - which are the main deterrents to adoption, are the economic criteria. Life-cycle GHG emissions per laundry wash in Sweden equal 130 grams, vis-à-vis the average of 330 grams for the 23 European countries studied by Shahmohammadi et al. (2018). This provides minimal incentive for the environmentallyconscious Swedes (specifically those who have assigned a high value to the criterion (d) in Table 1 and Table 2), to reduce their energy consumption by opting for a lower temperature setting as recommended by those authors. Doing so may not affect GHG consumption much, but will surely reduce the total household energy consumption. This may have a desirable reductive impact on resource consumption. The Likert's scale valuation followed by aggregation which was adopted in this survey, was also followed by Nakano S. et al. (2018), to categorise respondents as living in energy-efficient homes or not living in energy-efficient homes. While the average scores given to the investment cost and life-cycle cost (total cost in other words), were 2.78 and 2.63 (from Table 3 ) in our study, these two criteria for selection were ranked as very important by $49 \%$ and $42 \%$ of the respondents surveyed in Klepacka et al. (2018), respectively. In this survey, very few respondents assigned high values to the social criteria. Many assigned a value zero to the criteria ( $\mathrm{g}$ ) - being influenced by what the neighbours do, when it comes to energy-use-related behaviour. This, curiously is contradictory to the findings of some researchers. Solar PV installations are reported to have spread thanks to households imitating their neighbours. One cannot conclude from this survey of a little less than 300 households that Swedes are more individualistic by nature. However, one must not overlook the Hawthorne effect coming into play here.

The authors of this paper decided to limit the number of questions in the questionnaire to 20 , in order to improve the response rate. More questions may certainly have provided more information, but the number of respondents may have decreased. Palm (2018) for instance had over 40 questions in their survey, which elicited responses from 58 households in Sweden; while Nakano S. et al. (2018) had sixteen in their survey of 619 respondents. Interestingly, this gives a perfect-fit power-law relationship between number of questions and number of responses obtained. However, this relationship may still hold for web-based surveys in which participation is voluntary, and not for door-to-door surveys, in which the respondents commit before hand (informed consent, in other words) and abide by the comitment. This is evidenced by the 74-question survey conducted on-the-field by Matos et al. (2018) in which 245 responses were gathered for subsequent analysis. Vis-à-vis the sample sizes of the other studies listed in Table 1 above, this survey is quite comparable to Al Qadi et al. (2018), Jia et al. (2018), Matos et al. (2018), and for that matter, the sample subsets from each of the European countries studied in Thøgersen (2018).

\section{Conclusions and recommendations}

In this article, the authors have reviewed a selected set of papers published in 2018 and focusing on household surveys to understand attitudes and perceptions related to energy use and energy saving. The case studies encompass over 40 countries of the world. The methodology and results of a survey of nearly 300 households carried out in the city of Karlstad in Sweden, in which the sustainabilitythinking paradigm was applied, have been presented thereafter. This was followed by a discussion of the similarities to, and differences from some of the other published surveys reviewed earlier.

Even though most of the respondents in this sample set were employees or visiting researchers/faculty members at Karlstad University, when the survey was conducted, there was some diversity in the other descriptors. The ages of the respondents varied from 28 to 89 (the average being 51 years), while the ages of the single-family houses ranged from 3 to 300 years (when the year of initial construction was considered). Duration of home-ownership ranged from 6 months to 59 years. Both males and females were represented - a ratio of 9:8; which is more than the national gender ratio of 1.002 in 2017, as gathered from UN Data (2018). The number of members in the households ranged from 1 to 8 . While university-educated respondents dominated the sample, there were also some with lower levels of education (this, however, is not at all representative of the Swedish population as a whole). Small towns, mid-size towns, metropolitan cities and the countryside were all represented. Most households had a household income over 500,000 SEK. The precise value and thereby the per-capita household income were not determined. It is thereby not possible to say if the households in the sample set were representative of the whole country which had a national average annual household per-capita disapoable income of USD 30,553 in 2018, according to OECD Better Life Index (2018).

In order to find out the valuations that Swedes in general, would assign to the criteria within social, economic and environmental dimensions (and thereby to the dimensions themselves), the sample set has to be widened to encompass the whole of the country, making sure that more diversity can be be introduced in the process. The bi-modal approach could be modified to include additional modes of communicating with energy-users, and in-depth interviews can be conducted with some respondents to understand the thinking behind the responses. 
Some possible correlations (for instance, between age/level-of-education/gender/monthly household income and proclivity to any one of the three sustainability dimensions) which were not evident in this survey need to be tested with a much larger sample size.

In addition to determining the relative proclivities to the sustainability dimensions, it is also necessary to select a smaller group in which three equal subgroups can be identified, each weighting a different dimension higher than the other two; and obtain quantitative data on their actual annual energy use patterns (as also recommended by Nakano R. et al., (2018), and perhaps by using a gamified mobile application connected to smart meters like Wemyss et al. (2018) have done), and go further with timeuse-studies like Barthelmes et al. (2018) have done in the Danish case study. This would then lead to determining if any clear correlation exists between, for instance, the degree of environmental consciousness and actual energy use (or energy saving for that matter); or for that matter, a higher comfort-seeking behaviour and actual energy use. After all, as Nakano S. et al. (2018) have pointed out, and Thøgersen (2018) have investigated, while many people have the intention/attitude of being environmentally conscious and express this intention, not all of them take action. National weighting factors for the three dimensions can be subsequently derived, and compared with similar factors for other countries. However, these will need to be updated periodically.

\section{Acknowledgements}

We would like to express our warmest thanks to those collegues at Karlstad university who supported us with the survey and also to all the house-owners who spent time on the questionary. This work was supported by the Swedish Energy Agency under Grant number 42088-1.

\section{References}

1. AL QADI S., SODAGAR B. ELNOKALY A., 2018, Estimating the heating energy consumption of the residential buildings in Hebron, in: Palestine Journal of Cleaner Production, 196, p. 1292-1305.

2. ALLCOTT H., 2011, Social norms and energy conservation, in: Journal of Public Economics, 95(9), p. 1082-1095.

3. AMOAH A., HUGHES G. POMEYIE P., 2018, Environmental consciousness and choice of bulb for lighting in a developing country, in: Energy, Sustainability and Society, 8, p. 17, DOI: 10.1186/s13705-018-0159-y.

4. AUNE M., 2007, Energy comes home, in: Energy Policy, 35(11), p. 5457-5465.

5. BARTHELMES V.M., LI R., ANDERSEN R., BAHNFLETH W., CORNGNATI S.P., RODEA C., 2018, Profiling occupant behaviour in Danish dwell- ings using time use survey data, in: Energy and Buildings, 177, p. 329-340.

6. BENKA-COKER M.L., TADELE W., MILANO A., GETENEH D., STOKES H., 2018, A case study of the ethanol CleanCook stove intervention and potential scale-up in Ethiopia, in: Energy for Sustainable Development, 46: p. 53-64.

7. BURCHELL K., RETTIE R., ROBERTS T.C., 2016, Householder engagement with energy consumption feedback: the role of community action and communications, in: Energy Policy, 88, p. 178-186.

8. DARBY S., 1999, Energy advice - what is it worth, in: Proceedings, European Council for an Energy-Efficient Economy Summer Study, paper III, 5 , p. 3-05.

9. ELLEGÄRD K., PALM J., 2011, Visualizing energy consumption activities as a tool for making everyday life more sustainable, in: Applied Energy, 88(5), p. 1920-1926.

10. GANROT I., and EMANUELSSON C., 2017, Personal communication over the e-mail in 2017, Karlstad University.

11. GOULD C.F., URPELAINEN J., 2018, LPG as a clean cooking fuel: Adoption, use, and impact in rural India, in: Energy Policy, 122, p. 395-408.

12. JIA J-J., XU J-H., FAN Y., JI Q., 2018, Willingness to accept energy-saving measures and adoption barriers in the residential sector: An empirical analysis in Beijing, Chin, in: Renewable and Sustainable Energy Reviews, 95, p. 56-73.

13. KARYTSAS S., 2018, An empirical analysis on awareness and intention adoption of residential ground source heat pump systems in Greece, in: Energy Policy, 123, p. 167-179.

14. KIM M.-J., 2018, Characteristics and determinants by electricity consumption level of households in Korea, in: Energy Reports, 4, p. 70-76.

15. KJEANG A., G VENKATESH, STÄHL M., PALM J., 2017, Energy consulting services in the information age - literature review, in: Energy, Sustainability and Society, 7(30), DOI: 10.1186/s13705-017-0132-1.

16. KLEPACKA A.M., FLORKOWSKI W.J., MENGA T., 2018, Clean, accessible, and cost-saving: Reasons for rural household investment in solar panels in Poland, in: Resources, Conservation and Recycling, 139, p. 338-350.

17. KLÖCKNER C. A., 2015, The Psychology of ProEnvironmental Communication. Beyond Standard Information Strategies, Palgrave MacMillan.

18. MATOS C., BENTES I., PEREIRA S., GONĆALVES A.M., FARIA D., BRIGA-SÁ A., 2018, What are the factors that may explain the differences in water and energy consumption in urban and rural environments?, in: Science of the Total Environment, 642, p. 421-435.

19. MATOSOVIC M., TOMSIC Z., 2018, Modelling energy efficiency investment choice - a case study on Croatia's residential sector, in: Energy Sources, Part B: Economic, Planning and Policy, 13(7), p. 311319.

20. NAKANO R., ZUSMAN E., NUGROHO S., KASWANTO R.L., ARIFIN N., MUNANDAR A., ARIFIN H.S., MUCHTAR M., GOMI K., FUJITA T., 2018, Determinants of energy savings in Indonesia: The case of LED lighting in Bogo, in: Sustainable Cities and Society, 42, p. 184-193. 
21. NAKANO S., WASHIZU A., 2018, Acceptance of energy efficient homes in large Japanese cities: Understanding the inner process of home choice and residence satisfaction, in: Journal of Environmental Management, 225, p. 84-92.

22. OECD Better Life Index, 2018, Sweden, http://www. oecdbetterlifeindex.org/countries/sweden/ (25.09.2018)

23. PALM J., 2018, Household installation of solar panels - Motives and barriers in a 10 -year perspective, in: Energy Policy, 113, p. 1-8.

24. SCHULTZ P. et al., 2007, The Constructive, Destructive, and Reconstructive Power of Social Norms, in: Psychological Science, 18(5).

25. SHAHMOHAMMADI S., STEINMANN Z., CLAVREUL J., HENDRICK H., KING H., HUJIBREGTS M., 2018, Quantifying drivers of variability in life cycle greenhouse gas emissions of consumer products - a case study on laundry washing in Europe, in: International Journal of Life Cycle Assessment, 23, p. 1940-1949.
26. STEG L., 2008, Promoting household energy conservation, Energy Policy, 36, p. 4449-4453.

27. STERN P.C., 1992, What psychology knows about energy conservation, in: American Psychologist, 47 (10), p. 1224.

28. THØGERSEN J., 2018, Frugal or green - Basic drivers of energy saving in European households, in: Journal of Cleaner Production, 197, p. 1521-1530.

29. TJØRRING L., GAUSSET Q., 2015, 6 Energy renovation models in private households in Denmark, in: Community Governance and Citizen-Driven Initiatives in Climate Change Mitigation, 89.

30. UN, 2018, Statistics - Population by sex and urban/rural residence, Demographic Statistics Database, United Nations Statistics Division.

31. WEMYSS D., CELLINAC F., LOBSIGER-KÄGIB E., de LUCAD V., CASTRIC R., 2018, Does it last? Long-term impacts of an app-based behaviour change intervention on household electricity savings in Switzerland, in: Energy Research and Social Science, 47, p. 16-27. 